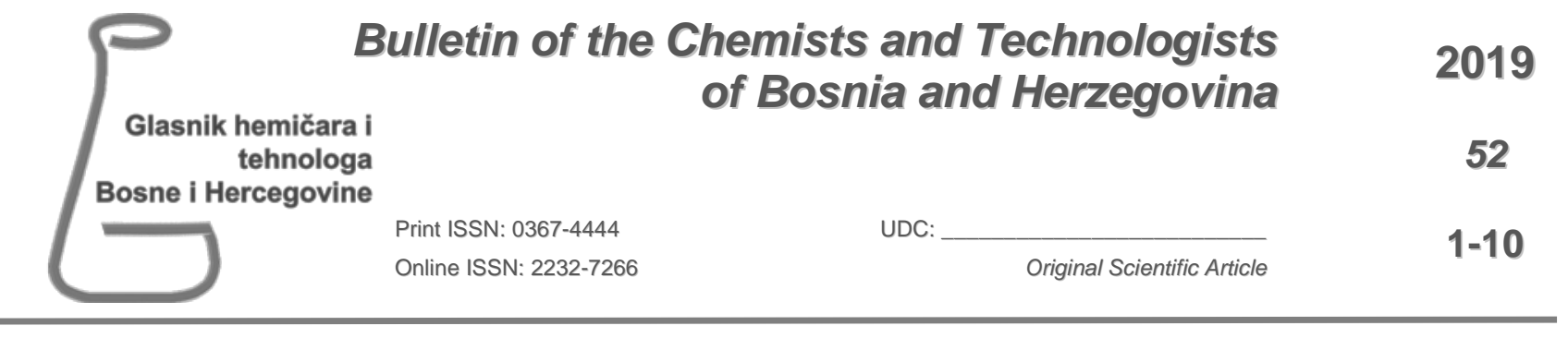

\title{
Inhibition of Iron Corrosion in Seawater Using Rosemary Extracts (Rosmarinus officinalis L.)
}

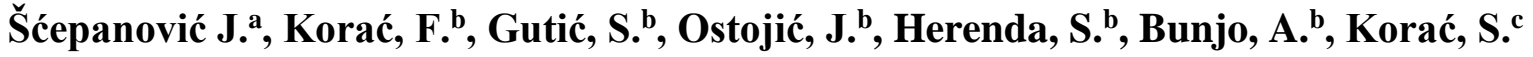 \\ ${ }^{a}$ Faculty of Metallurgy and Technology, Podgorica, University of Montenegro \\ ${ }^{b}$ Department of Chemistry, Faculty of Science, University of Sarajevo, Sarajevo, Bosnia and Herzegovina \\ ${ }^{c}$ Faculty of Pharmacy, University of Sarajevo, Zmaja od Bosne 8, 71000 Sarajevo, Bosnia and Herzegovina
}

\section{Article info}

Received: 18/03/2019

Accepted: 10/04/2019

Keywords:

Iron

Corrosion Inhibition

Environmentally

Acceptable Inhibitors

Rosemary

*Corresponding author:

Fehim Korać

E-mail: fkorac@pmf.unsa.ba

\begin{abstract}
Due to a growing awareness of environmental protection, an interest in replacing toxic corrosion inhibitors with more environmentally acceptable alternatives is also growing. Chromates, as one of the best inhibitors, have been eliminated as technically viable inhibitors because of their high toxicity, and the use of polyphosphates has diminished as they disrupt the balance in the Plantae kingdom. The emphasis is on exploration and testing of organic compounds that can be obtained from plant material. Rosemary extracts (leaf and flower) have been shown to have inhibitory activity on iron corrosion in $3 \% \mathrm{NaCl}$ and seawater. Corrosion rate values show that rosemary flower extracts are better inhibitors of corrosion than the leaf extracts and that the maximum inhibitory protection has not been achieved in the range of tested concentrations.
\end{abstract}

\section{INTRODUCTION}

Due to the development of industry, especially in the technological aspect, various types and forms of corrosion of metal and non-metallic materials are present. The reason for this is the rapid increase in the number of objects, devices, constructions, as well as the higher pollution intensity due to combustion of solid and liquid fuels (Kliškić, 2000).

In order to reduce the corrosion rate, except for the usual coatings, number of inhibitors are used. Inhibitors are substances which, when added to a corrosive environment, reduce corrosion rates to technologically acceptable rates (Pupovac, 2008). In order to meet the needs to preserve the environment, environmentally acceptable inhibitors are being used more often. This is particularly the case for extracts of various plants, which in their composition have compounds that can slow down the corrosion process (Radošević, 2012); (Pallav, 2014). Phenolic compounds have shown quite good protective properties, above all flavonoids. Some of them show the possibility of creating metal chelate complexes. (Radosevic, 2012-1); (Hogervorst Cvejić, 2016). Rosemary shows the ability to inhibit the corrosion of metals and metal alloys. Organic compounds containing heteroatoms such as sulfur, nitrogen or oxygen in their structure have shown to have a tendency to adsorb onto metal surfaces, creating a protective layer that can slow down the development of corrosion (Khan, 2015). Green corrosion inhibitors are biodegradable, do not contain heavy metals or other toxic components, so they are increasingly applied instead of chemicals, mainly toxic inhibitors. 
The first step in the activation mechanism of these compounds is the adsorption on the metal surface. For the dissolution of the adsorption process it is necessary to have forces of attraction between the adsorbate and the metal surface. In adsorbed molecules, hemisorption can occur in the presence of heteroatoms (P, Se, S, N, O) with lone electron pairs, or aromatic rings. Decrease in the rate of cathodic or anodic or both reactions arises from the adsorption of inhibitors at the active corrosion points on the surface of the metal (Ahamad, 2010).

\section{Rosemary}

Rosemary (Rosmarinus officinalis L.) is a woody, perennial herb with fragrant, evergreen leaves and very small light-blue flowers. The leaves are very narrow, firm, leathery and 2-3 cm long. It is native to the Mediterranean region, where it grows on calcium rich soil, in dry climate and in salty sea air. The plants grow 1$3 \mathrm{~m}$ in height. Rosemary extracts include phenolic compounds (carnosol, carnosic acid, rosmanol), cinnamic acid derivatives (rosmarinic acids) and flavonoids (nepetin, nepitrin). The leaves also contain triterpenes such as ursolic acid (Velázquez-Gonzalez, 2014). Rosmarinic acid, carnosol and carnosic acid represent the most significant phenolic compounds of rosemary, with outstanding antioxidant properties (Erkan, 2008, BorrásLinares, 2014). Carnosic acid has lipophilic properties, and rosmarinic acid is hydrophilic, so rosemary extracts can be used to prevent oxidation of both polar and nonpolar nutritional products (Berdahl, 2015).

The sampled plant was collected in the area of Split, Croatia. The sampling was done on June $2^{\text {th }} 2017$.

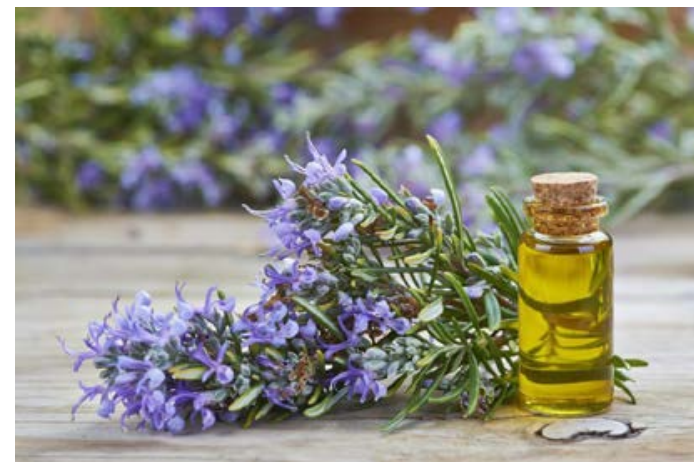

Figure 1. Rosemary

\section{EXPERIMENTAL}

\section{Preparation of samples}

\section{Reflux extraction}

Dried rosemary leaves were ground into fine powder, weighed out 15 grams and immersed in $100 \mathrm{~mL}$ of solvent, i.e. redistilled water in a flask fitted to a condenser.

The solvent is heated until boiling. As the solvent evaporates, it enters the condenser where it condenses and returns to the flask. The extraction is carried out for one hour, followed by filtration through $110 \mathrm{~mm}$ filter paper - black ribbon and the resulting aqueous extract volumewas the total volume. The same procedure was carried out with rosemary flower.

Determination of total phenolic compounds content (Folin-Ciocalteau method)

In a series of $10 \mathrm{~mL}$ volumetric flasks, $200 \mu \mathrm{l}$ of the sample of known concentrations was measured and dilute with about $6 \mathrm{~mL}$ of distilled water. $500 \mu \mathrm{L}$ of Folin - Ciocalteu reagent was added, previously diluted with water in a ratio of 1:2. After 5-10 minutes, $1.5 \mathrm{~mL}$ of a $20 \%$ sodium carbonate solution was added and dilute the resulting mixture with water to $10 \mathrm{~mL}$. Prepared samples are left $2 \mathrm{~h}$ to stand at room temperature and their absorbance was measured at $765 \mathrm{~nm}$. (Pavagada, 2010)

The total content of phenolic compounds is determined based on the calibration curve for gallic acid at the concentration range of 0.01-1.10 mg / mL.

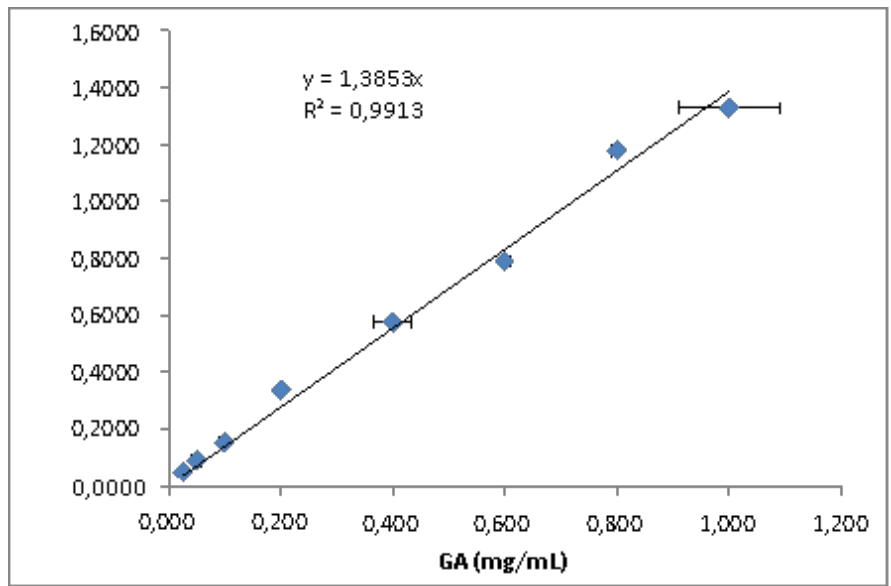

Figure 2. Calibration curve for the determination of total phenolic content 
Table 1. Determination of concentration of phenolic compounds in the samples

\begin{tabular}{|c|c|c|c|c|c|c|c|c|c|c|c|c|c|c|c|c|c|}
\hline $\begin{array}{l}\frac{0}{0} \\
\text { हू } \\
\text { हn }\end{array}$ & $\begin{array}{l}\frac{\overrightarrow{\vec{g}}}{\underline{\underline{\xi}}} \\
\frac{\hat{\xi}}{\lambda}\end{array}$ & $\frac{\overrightarrow{\vec{\varepsilon}}}{>}$ & 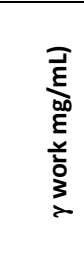 & z & 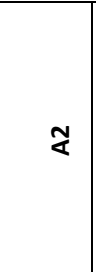 & qu & 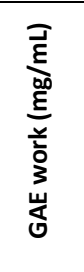 & 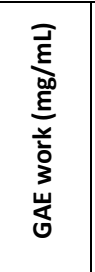 & 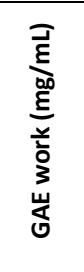 & 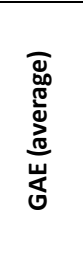 & 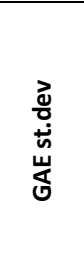 & 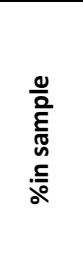 & 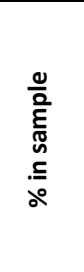 & 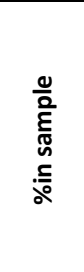 & 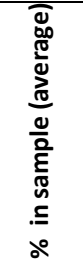 & 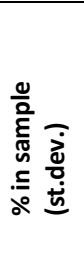 & 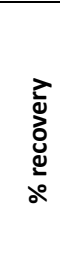 \\
\hline \multirow{3}{*}{ Flower } & 105,11 & 0,10 & 35,04 & 0,1954 & 0,1866 & 0,1747 & 0,1411 & 0,1347 & 0,1261 & \multirow{3}{*}{0,2108} & \multirow{3}{*}{0,0899} & & & & \multirow{3}{*}{0,0029} & \multirow{3}{*}{0,0002} & \multirow{3}{*}{7,90} \\
\hline & 105,11 & 0,20 & 70,07 & 0,2849 & 0,301 & 0,3104 & 0,2057 & 0,2173 & 0,2241 & & & 0,0029 & 0,0031 & 0,0032 & & & \\
\hline & 105,11 & 0,30 & 105,11 & 0,3934 & 0,3899 & 0,3923 & 0,2840 & 0,2815 & 0,2832 & & & 0,0027 & 0,0027 & 0,0027 & & & \\
\hline \multirow{3}{*}{ Leaf } & 1,68 & 0,10 & 0,56 & 0,4407 & 0,4521 & 0,4554 & 0,3181 & 0,3264 & 0,3287 & \multirow{3}{*}{0,4653} & \multirow{3}{*}{0,1613} & & & & \multirow{3}{*}{0,3903} & \multirow{3}{*}{0,0415} & \multirow{3}{*}{10,62} \\
\hline & 1,68 & 0,20 & 1,12 & 0,6646 & 0,6652 & 0,6629 & 0,4798 & 0,4802 & 0,4785 & & & 0,4283 & 0,4287 & 0,4273 & & & \\
\hline & 1,68 & 0,30 & 1,68 & 0,8222 & 0,8202 & 0,8182 & 0,5935 & 0,5921 & 0,5906 & & & 0,3533 & 0,3524 & 0,3516 & & & \\
\hline
\end{tabular}

It is necessary to determine the optimal concentrations of inhibitors because not every concentration is effective. Excessive or insufficient concentration of inhibitors can have an activating effect on corrosion of metals and the opposite effect of the desired one can be achieved. The inhibitor must be able to inhibit corrosion but also be present in the appropriate amount on the surface of the metal to demonstrate efficacy. Some inhibitors, if not present in sufficient concentration, may alter the corrosion distribution, but not the corrosion intensity. Therefore, it is necessary for each individual system to determine the concentration of the inhibitor that effectively protects against corrosion. Due to environmental and economic reasons, excessive consumption of inhibitors should be avoided. (Stupnišek - Lisac, 2007).

\section{Preparation of iron tiles}

The iron sampleswere sanded, first with fine sanding paper and rinsed with distilled water. Subsequently, they were immersed in a degreasing solution, heated to 90$95^{\circ} \mathrm{C}$ and held in it for 15-20 minutes. After degreasing, the samples are rinsed with warm, then cold water. The samples are then subjected to corrosion for 5 to 10 minutes. After corrosion and rinsing with cold water, the samples are briefly immersed in $3 \% \mathrm{H}_{2} \mathrm{SO}_{4}$ solution. (Burovic, 2018).

Seawater was used for electrochemical testing. As a standard corrosive medium, $3 \% \mathrm{NaCl}$ solution was used.

\section{Work process}

After adequately preparing the samples, iron plates were exposed to the corrosion media. For the linear polarisation and potentiodinamic experiments, PAR 263A potentiometer / galvanostat connected to the computer, with Power CV software was used. The measurements were performed in an electrochemical cell equipped with three electrodes (working, $\mathrm{Ag} / \mathrm{AgCl}$ as reference and $\mathrm{Pt}$ as auxiliary electrode) at $25^{\circ} \mathrm{C}$. The sample was polished using the $\mathrm{Al} 2 \mathrm{O} 3$ powder. After coating the working electrode with teflon tape, the plate was immersed in the activating solution $\left[\mathrm{V}\left(\mathrm{H}_{2} \mathrm{SO}_{4}\right.\right.$, conc): $\mathrm{V}\left(\mathrm{H}_{2} \mathrm{O}_{2}\right.$, conc $)=1: 1$ ) for one minute and then rinsed with distilled water. $40 \mathrm{~mL}$ of corrosive medium is added to the electrochemical cell and then the electrode were submerged in the solution. The linear polarization measurements were performed $\pm 25 \mathrm{mV}$ from the corrosion potential Ecorr, which was determined by a potentiodynamic method in a wider range of potentials at a scan rate of $0,166 \mathrm{mV} / \mathrm{s}$ (Korać, 2010). The reference diagrams were recorded $\pm 250 \mathrm{mV}$ in relation to the mentioned potential.

\section{RESULTS AND DISCUSSION}

Iron plates without inhibitors

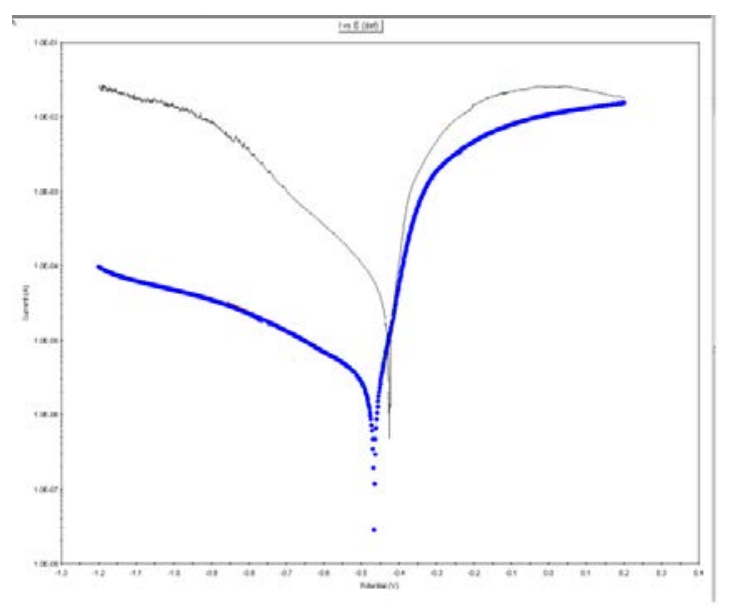

Figure 3. Tafel diagrams for the iron plate in 3\% $\mathrm{NaCl}$ solution; SW wihout inhibitors

From the voltamogram it is noticeable that there is a certain passivation in the anode direction that is characteristic of the iron sample used for testing. Such behavior was repeated on all other test results. 
- Iron plates in 3\% NaCl solutions, with rosemary leaf extracts of various concentrations

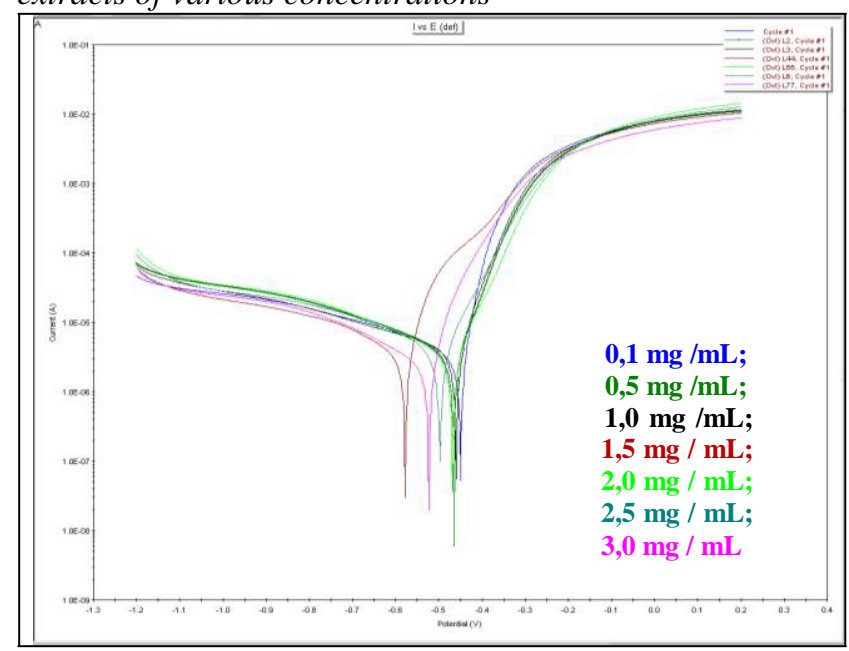

Figure 4. Tafel diagram, inhibitory activity of rosemary leaf extracts of various concentrations in $3 \% \mathrm{NaCl}$ solution

The same phenomenon of passivation is repeated in the application of inhibitors, but there is no longer a scattering of results as in the measurement with no used extracts. The reason for this can be the formation of a protective layer of metallocomplex that equalizes the surface and makes the surface behave uniformly in the action of the corrosion medium.

- Iron plates in seawater, with rosemary leaf extracts of various concentrations

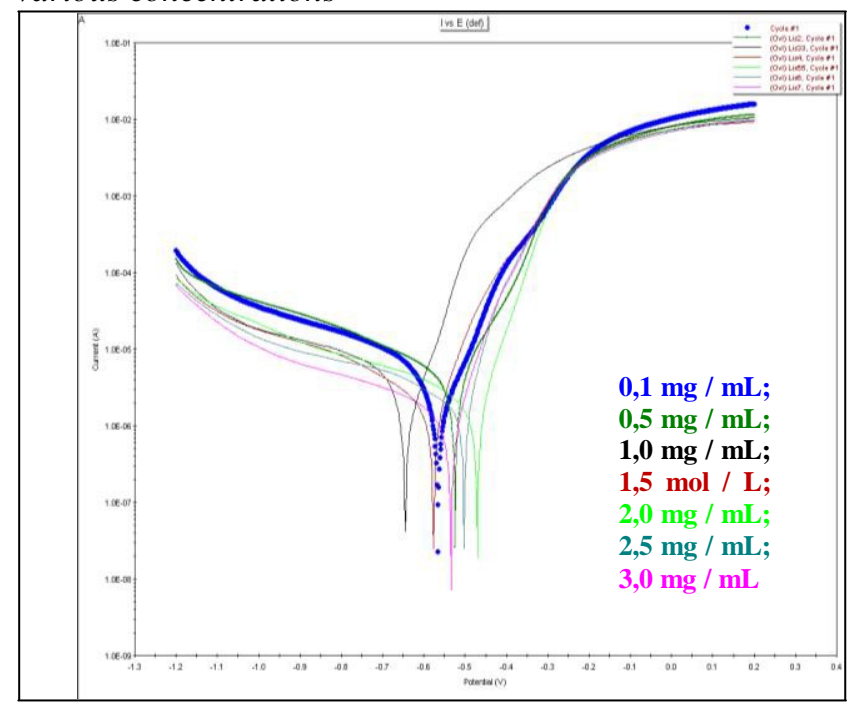

Figure 5. Tafel diagram, inhibitory activity of rosemary

leaf extracts of various concentrations in seawater

The regularity is repeated in the seawater. More detailed parameters of the behavior of iron in seawater are given by corrosion parameters obtained from these voltamograms.
- Iron plates in 3\% $\mathrm{NaCl}$ solution, with rosemary flower extracts of various concentrations

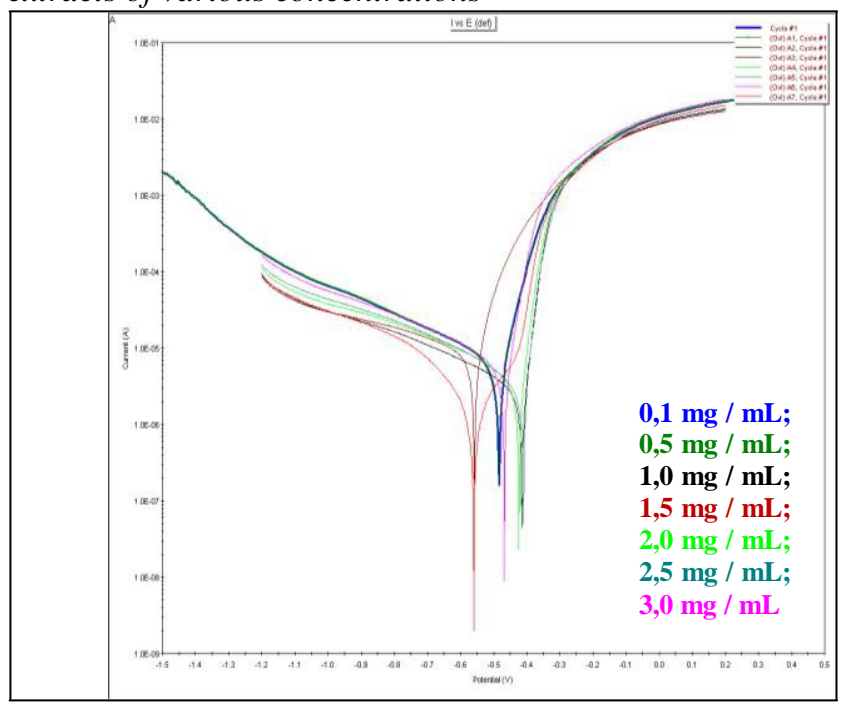

Figure 6. Tafel diagram, inhibitory activity of rosemary flower extracts of various concentrations in $3 \% \mathrm{NaCl}$ solution

The rosemary flower extract behaves in a very similar manner as the leaf extract. By increasing the concentration of the extract, the correct displacement of Tafel curves can be noticed.

- Iron plates in seawater, with rosemary flower extracts of various concentrations

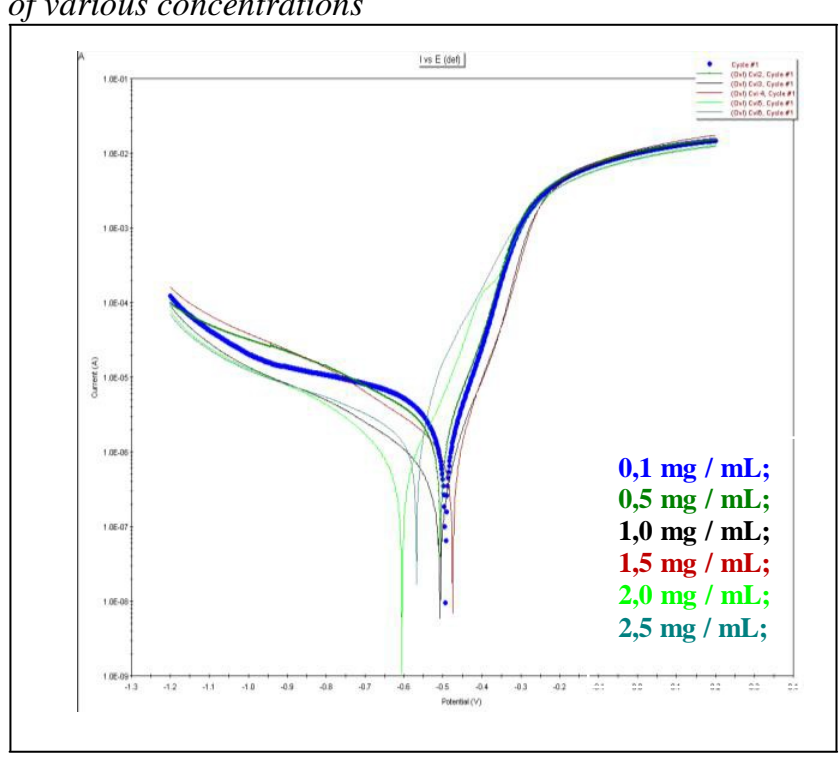

Figure 7. Tafel diagram, inhibitory activity of rosemary flower extracts of various concentrations in seawater

Rosemary flower extracts in seawater have a similar corrosion profile as previous cases.

By comparing all the results of the measurements, it can be seen which conditions of corrosion and concentration of individual leaf and flower extracts provide suitable combinations for the most efficient protection of iron with environmentally acceptable inhibitors. It is necessary to bear in mind the stability and biodegradability of the metallocomplex, and from the economic point of view the amount of inhibitors that will show the optimal protection role. 
Corrosion potential is derived from Tafel diagrams (Figures 3 to 7). Using the method of extrapolation of the direction of the cathodic and anodic curves, Tafel's constants $\beta_{\mathrm{A}}$ and $\beta_{\mathrm{K}}$ were determined Corrosion current and corrosion rate values will to be shown in the following tables.

Table 2. The measurement results for iron plates in $3 \% \mathrm{NaCl}$ solution, without and in the presence of rosemary leaf extract

\begin{tabular}{|c|c|c|c|c|c|c|}
\hline $\mathrm{mg} / \mathrm{mL}$ & $\begin{array}{l}E_{\text {corr }} \\
{[\mathrm{mV}]}\end{array}$ & $\beta_{\mathrm{A}}[\mathrm{mV} / \mathrm{dec}]$ & $\beta_{K}[\mathrm{mV} / \mathrm{dec}]$ & $R \mathrm{p}[\mathrm{mV} / \mu \mathrm{A}]$ & $\left.\mathrm{i}[\mu \mathrm{A}] / \mathrm{cm}^{2}\right]$ & $\mathrm{v}[\mathrm{mm} / \mathrm{y}]$ \\
\hline 0 & -466 & 0,037175 & 0,073099 & 0,000132 & 3,40999 & 0,046509 \\
\hline 0,1 & -450 & 0,037051 & 0,051414 & 0,000148 & 3,135528 & 0,045004 \\
\hline 0,5 & -465 & 0,055804 & 0,214592 & 0,000169 & 3,061832 & 0,048191 \\
\hline 1 & -459 & 0,064103 & 0,058789 & 0,000181 & 2,981226 & 0,041393 \\
\hline 1,5 & -589 & 0,041806 & 0,086881 & 0,0002055 & 2,90949 & 0,037791 \\
\hline 2 & -461 & 0,048685 & 0,136503 & 0,000253 & 2,78408 & 0,034914 \\
\hline 2,5 & -497 & 0,084674 & 0,196155 & 0,000251 & 2,788049 & 0,035523 \\
\hline 3 & -516 & 0,089206 & 0,515198 & 0,000267 & 2,668114 & 0,031289 \\
\hline
\end{tabular}

Table 3. The measurement results for iron plates in seawater, without and in the presence of rosemary leaf extract

\begin{tabular}{|c|c|c|c|c|c|c|}
\hline $\mathrm{mg} / \mathrm{mL}$ & $\begin{array}{l}\mathrm{E}_{\text {corr }} \\
{[\mathrm{mV}]}\end{array}$ & $\beta_{\mathrm{A}}[\mathrm{mV} / \mathrm{dec}]$ & $\beta_{K}[\mathrm{mV} / \mathrm{dec}]$ & $\mathrm{Rp}[\mathrm{mV} / \mu \mathrm{A}]$ & $\left.\mathrm{i}[\mu \mathrm{A}] / \mathrm{cm}^{2}\right]$ & $\mathrm{v}[\mathrm{mm} / \mathrm{y}]$ \\
\hline 0 & -420 & 0,042662 & 0,115075 & $6,11 \mathrm{E}-05$ & 2,826804 & 0,03468 \\
\hline 0,1 & -565 & 0,088968 & 0,131822 & $8,46 \mathrm{E}-05$ & 2,95382 & 0,032876 \\
\hline 0,5 & -524 & 0,081566 & 0,261917 & 0,000101 & 2,764258 & 0,034073 \\
\hline 1 & -521 & 0,096061 & 0,213129 & $1,29 \mathrm{E}-04$ & 2,694553 & 0,031353 \\
\hline 1,5 & -576 & 0,095602 & 0,695894 & $1,35 \mathrm{E}-04$ & 2,368884 & 0,027736 \\
\hline 2 & -549 & 0,082034 & 0,569152 & $1,22 \mathrm{E}-04$ & 2,347532 & 0,026827 \\
\hline 2,5 & -502 & 0,072254 & 0,263158 & $1,50 \mathrm{E}-04$ & 2,25243 & 0,023714 \\
\hline 3 & -534 & 0,072993 & 0,348068 & $1,53 \mathrm{E}-04$ & 2,24557 & 0,021634 \\
\hline
\end{tabular}

Table 4. The measurement results for iron plates in $3 \% \mathrm{NaCl}$, without and in the presence of rosemary flower extract

\begin{tabular}{|c|c|c|c|c|c|c|}
\hline $\mathrm{mg} / \mathrm{mL}$ & $E_{\text {corr }}[\mathrm{mV}]$ & $\beta_{\mathrm{A}}[\mathrm{mV} / \mathrm{dec}]$ & $\beta_{\mathrm{K}}[\mathrm{mV} / \mathrm{dec}]$ & $\mathrm{Rp}[\mathrm{mV} / \mu \mathrm{AA}]$ & $\left.\mathrm{i}[\mu \mathrm{AA}] / \mathrm{cm}^{2}\right]$ & $\mathrm{v}[\mathrm{mm} / \mathrm{y}]$ \\
\hline 0 & -466 & 0,037175 & 0,073099 & 0,000132 & 3,40999 & 0,046509 \\
\hline 0,1 & -411 & 0,028498 & 0,083472 & 0,000119 & 2,223813 & 0,028696 \\
\hline 0,5 & -414 & 0,03023 & 0,163934 & 0,000196 & 2,178352 & 0,025505 \\
\hline 1 & -558 & 0,036689 & 0,087336 & 0,000225 & 2,061973 & 0,024926 \\
\hline 1,5 & -424 & 0,031437 & 0,049188 & 0,000237 & 1,925288 & 0,0222 \\
\hline 2 & -410 & 0,031368 & 0,046598 & 0,000257 & 1,890771 & 0,02448 \\
\hline 2,5 & -468 & 0,041528 & 0,048567 & 0,000271 & 1,608102 & 0,020245 \\
\hline 3 & -560 & 0,041391 & 0,07446 & 0,000314 & 1,353771 & 0,019559 \\
\hline
\end{tabular}

Table 5. The measurement results for iron plates in seawater, without and in the presence of rosemary flower extract

\begin{tabular}{|c|c|c|c|c|c|c|}
\hline $\mathrm{mg} / \mathrm{mL}$ & $\mathrm{E}_{\text {corr }}[\mathrm{mV}]$ & $\beta_{\mathrm{A}}[\mathrm{mV} / \mathrm{dec}]$ & $\beta_{\mathrm{K}}[\mathrm{mV} / \mathrm{dec}]$ & $\mathrm{Rp}[\mathrm{mV} / \mu \mathrm{A}]$ & $\left.\mathrm{i}[\mu \mathrm{A}] / \mathrm{cm}^{2}\right]$ & $\mathrm{v}[\mathrm{mm} / \mathrm{y}]$ \\
\hline 0 & -420 & 0,042662 & 0,115075 & $6,11 \mathrm{E}-05$ & 2,826804 & 0,03468 \\
\hline 0,1 & -494 & 0,060024 & 0,087184 & 0,000066 & 2,020109 & 0,019944 \\
\hline 0,5 & -506 & 0,0815 & 0,36062 & $6,73 \mathrm{E}-05$ & 1,944281 & 0,017764 \\
\hline 1 & -508 & 0,059137 & 0,096974 & $7,70 \mathrm{E}-05$ & 1,923125 & 0,012612 \\
\hline 1,5 & -475 & 0,072202 & 0,240906 & $8,13 \mathrm{E}-05$ & 1,907821 & 0,011332 \\
\hline 2 & -605 & 0,081301 & 0,128469 & $9,16 \mathrm{E}-05$ & 1,872797 & 0,010536 \\
\hline 2,5 & -568 & 0,079239 & 0,29967 & $1,03 \mathrm{E}-04$ & 1,312477 & 0,009392 \\
\hline 3 & -590 & 0,106304 & 0,329815 & 0,000107 & 1,2733 & 0,00707 \\
\hline
\end{tabular}

Data from Table 2 to Table 5 are presented in a Figure 8. 


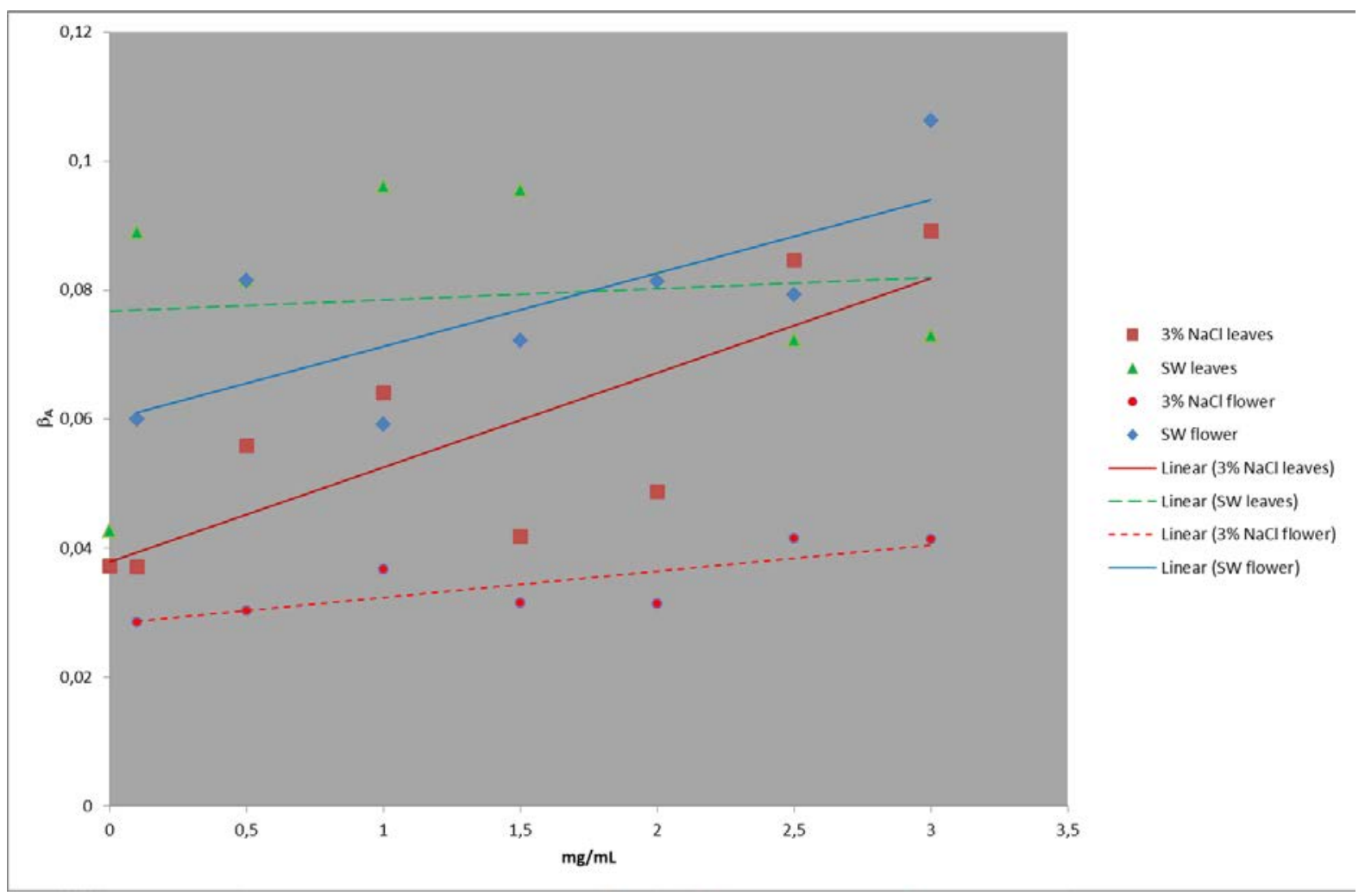

Figure 8. Dependence of Tafel's anodic slope of different concentrations of inhibitors in various corrosion media

From Figure 8 it can be concluded that the value of Tafel's anodic slope increases with the change of concentrations of extracts in both corrosion media as well as in both extracts. It can be noted that inhibitors derived from plant extracts affect the anodic reaction and alter it. A slight effect on the anodic reaction is shown. In these measurements, when a significant change in the rate of corrosion occurs, it appears that the inhibitor also affects the cathodic reaction in the given system.

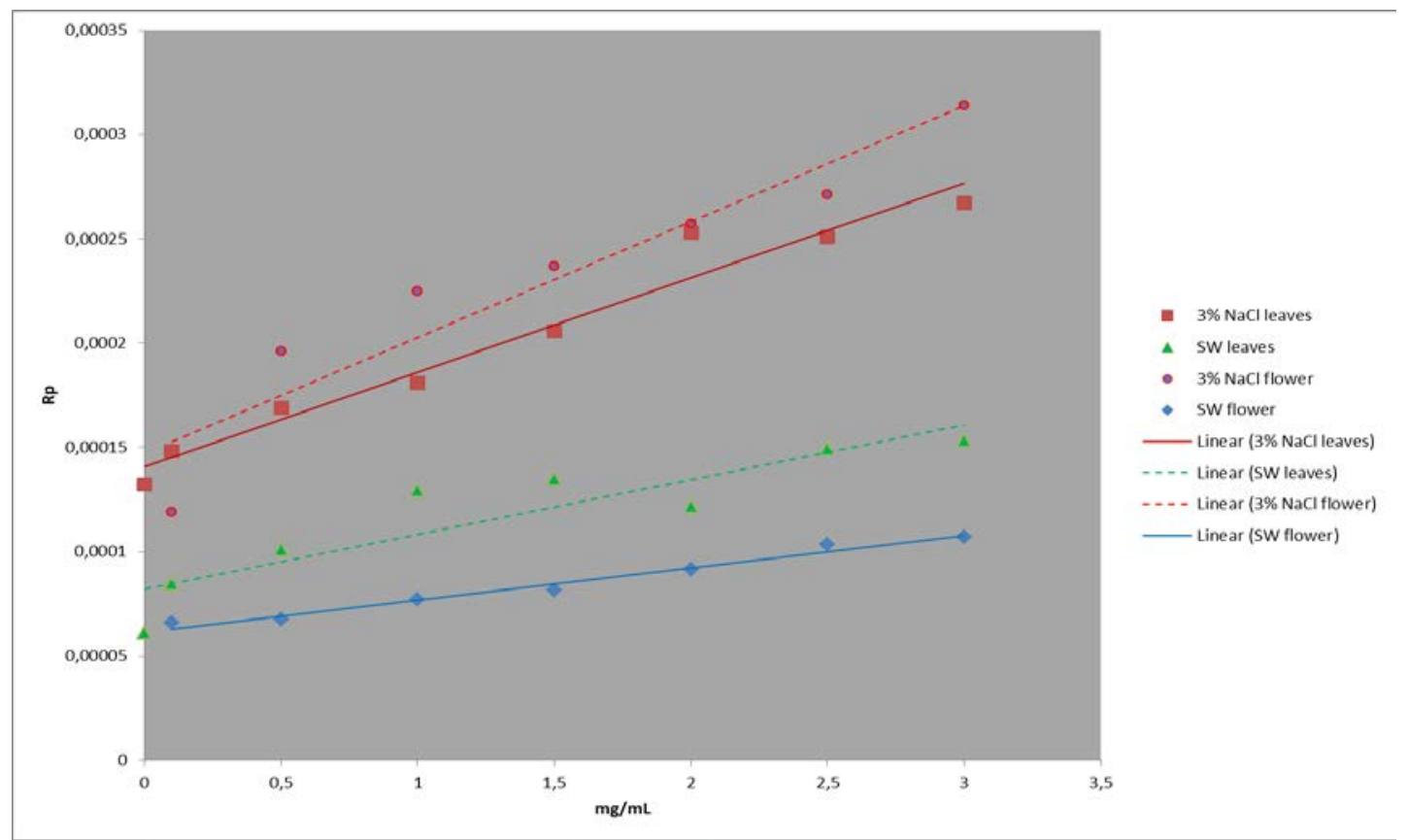

Figure 9. Dependence of polarization resistance of different inhibitor concentrations in various corrosive media extracts than in flower extracts. Polarization

From Figure 9 it can be concluded that the values of polarization resistances are higher in the leaf resistance values show higher value for samples 
that have better protection.. Based on these values of $\mathrm{Rp}$, it can be assumed that the creation of a protective layer on the surface of the metal that changes the electrical conductivity is present. Due to the structure of this film, it can also be said that there is a less conductive form which also contains organic components that produce relatively stable complexes with the metal.

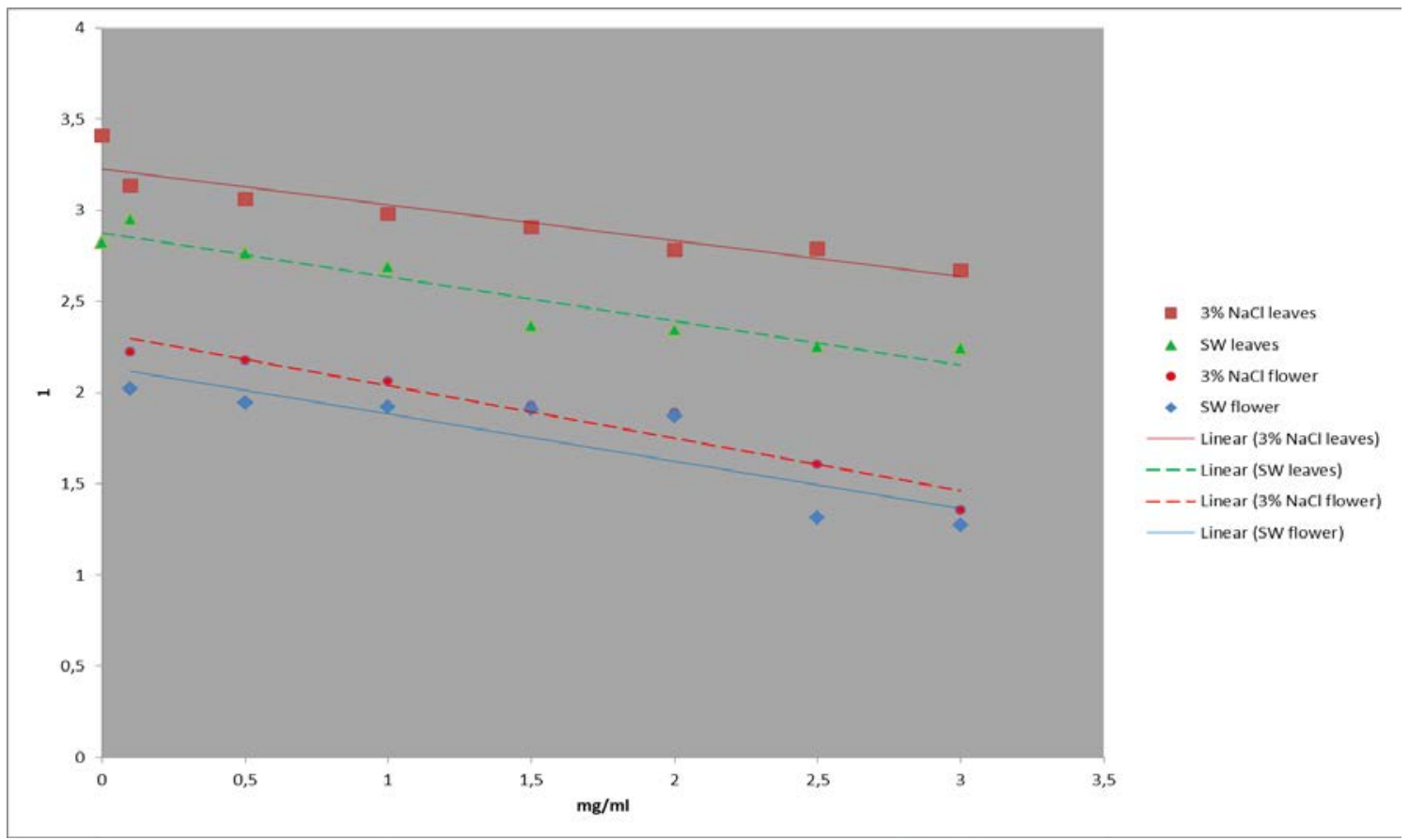

Figure 10. Dependence of corrosion current of different inhibitor concentrations in various corrosive media

Corrosion current can also be used as an indicator of inhibitory activity. The lower the corrosion current value, the more effective the inhibitor is. Figure 10 shows that flower extracts are more effective than leaf extracts. Also the marine environment is less aggressive than the $3 \% \mathrm{NaCl}$ solution. It can be concluded that some seawater compounds further inhibit iron corrosion.
It is shown that, due to the action of the protective film, the increase in the concentration of the inhibitor decreases the corrosion current because it reduces the conductivity and accessibility of the metal in the structure to the action of the corrosion environment.

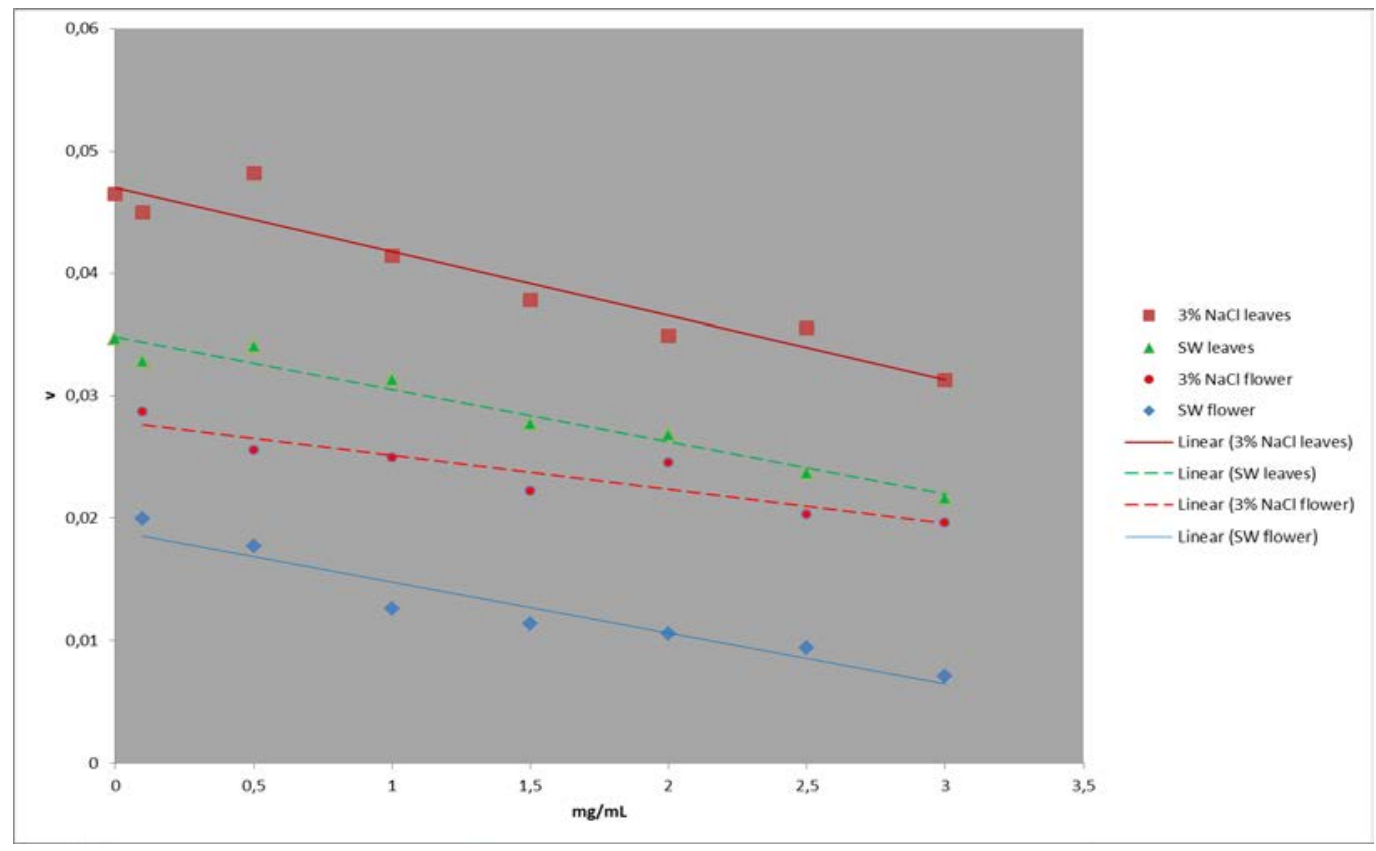

Figure 11. Dependence of corrosion rate of different inhibitor concentrations in various corrosive media 
As corrosion currents demonstrate the efficacy of inhibitors, the corrosion rate is also a measure of protective activity. The lower the rate, the greater the efficiency of the inhibitor.

From Figure 11 it is concluded that when the flower extract is more efficient, the corrosion rate is lower, and that $3 \% \mathrm{NaCl}$ solution is less suitable for the formation of the metal complex layer on the surface of the metal. It is assumed that the resulting metal complexes become passivated on the surface and that it is less soluble than in 3\% $\mathrm{NaCl}$ solution.

Based on the experiences observed, it was expected that some concentrations would significantly alter the mechanism of action of inhibitors that would be reflected in a noticeable change in the rate of corrosion. It was not seen here. The reason for this may be that the entire surface of the metal is equally covered by a protective layer of metallocomplex that would more effectively protect the metal from the action of the corrosion environment. Due to the complexity of seawater composition, better coverage of metals and lower corrosion rate were observed.

\section{CONCLUSIONS}

Based on the results of the research, general conclusions can be drawn.

- Based on the concentrations and calibration curves of gallic acid, the content of phenolic compounds in leaf extracts and rosemary blossoms can be determined;

- $\quad$ Rosemary (leaf and flower) extracts can be used as an iron corrosion inhibitor in seawater;

- Rosemary flower extract was shown to be a better inhibitor than leaf extract.

From the values of Rp, $\mathrm{v}_{\text {corr }}$ and Tafel's anodic slope it can also be concluded that:

- the value of Tafel's anodic slope increases with the change of concentrations of extracts in both the corrosion media, as well as in both extracts;

- the polarization resistance values are higher in the leaf extract than in the flower extract. Polarization resistance shows higher value for samples that have better protection;

- Flower extracts are more effective inhibitors than leaf extracts. Also, the marine environment is less aggressive than the $3 \% \mathrm{NaCl}$ solution. It can be concluded that some seawater compounds further inhibit iron corrosion;

- the flower extract is more efficient, the corrosion rate is lower, and that $3 \% \mathrm{NaCl}$ solution is less suitable for the formation of the metal complex layer on the surface of the metal;

- It is assumed that the resulting metal complexes become passivated on the surface and that it is less soluble than in $3 \% \mathrm{NaCl}$ solution;

- There was no stagnation in one of the parameters, to conclude that there was no complete overcoating of the surface with the protective layer and that this protective effect could be improved.

\section{REFERENCES}

Ahamad, I., Quraishi M.A. (2010) Mebendazole: New and efficient corrosion inhibitor for mild steel in acid medium, Corrosion Science 52, 651-656.

Berdahl, D. R., McKeague, J. (2015) Rosemary and sage extracts as antioxidants for food preservation. U: Handbook of antioxidants for food preservation. (Shahidi, F., ured.) Woodhead Publishing, Cambridge/Waltham/Kidlington, p. 117-217.

Borrás-Linares, I., Stojanović, Z., Quirantes-Piné, R., Arráez-Román, D., Švarc-Gajić, J., FernándezGutiérrez, A., Segura-Carretero, A. (2014) Rosmarinus officinalis leaves as a natural source of bioactive compounds. Int. J. Mol. Sci. 15, 2058520606.

Burović, S., Korać, F., Huremović, J., Ostojić, J.(2018): Atmospheric Corrosion of Metals in Urban Area. Bulletin of the Chemists and Technologists of Bosnia and Herzegovina. 51. p 25-33

Erkan, N., Ayranci, G., Ayranci, E. (2008) Antioxidant activities od rosemary (Rosmarinus Officinalis L.) extract, blackseed (Nigella sativa L.) essentiall oil, carnosic acid, rosmarinic acid and sesamol. Food Chem. 110, 76-82.

Hogervorst Cvejić, J., Atanacković Krstonošić, M., Bursać, M., Miljić, U. (2017) Polyphenols. U: Nutraceutical and functional food components: Effects of innovative processing techniques. (Galanakis, C. M., ured.) Academic press. Amsterdam/ Boston/ Heidelberg/ London/ New York/ San Francisco/ Singapore/ Sydney/ Tokyo, p. 203-237.

Khan, G., Salim Newaz, K. M., Basirun, W. J., Mohd Ali, H. B., Lafta Faraj, F., Khan, G. M. (2015) Application of natural products extracts as green corrosion inhibitors for metals and alloys in acid pickling processes - a review. Int. J. Electrochem. Sci. 10, 6120-6134.

Kliščić, M., Radošević, J., Gudić, S. and Katalinić, V.(2000): Aqueous extract of Rosmarinus officinalis 
L. as inhibitor of Al-Mg alloy corrosion in chloride solution. Journal of Applied Electrochemistry 30: 823-830.

Korać F., Ćatić S., Cacan M., Gutić S., Islamović S. (2010): Investigation of Pitting Corrosion on Orthopedic Implant in Physiological Solutions. Materials Protection, 51 Vol.2, 99 - 103 (original name of paper and journal: Tačkasta korozija ortopedskog implantata u fiziološkim rastvorima. Zaštita materijala)

Pallav Shah, Shruti Agarwal: Aloe-Vera (2014): A Green Corrosion Inhibitor. International Journal For Research In Applied Science And Engeineering Technology, Vol. 2 Issue V, May 2014

Pavagada Jagannathamurthy Ramesh, Kanakapura Basavaiah, Nagaraju Rajendraprasad (2010): Sensitive and selective spectrophotometric assay of doxycycline hyclate in pharmaceuticals using FolinCiocalteu reagent. Acta Pharm. 60. p 445-454

Pupovac, M. (2008).: Corrosion Inhibition by Natural Compounds, Faculty of Food Technology and Biotechnology, University of Zagreb. (original name of paper and journal: Inhibicija korozije prirodnim spojevima, Prehrambeno-biotehnološki fakultet, Sveučilišta u Zagrebu. )
Radošević, J. (2012): Eco-friendly Corrosion Inhibitors of Aluminum and Copper Alloys. Faculty of Chemistry and Technology, Split. (original name of paper and journal: Ekološki prihvatljivi inhibitori korozije legura aluminija i bakra. Kemijskotehnološki fakultet, Split.)

Radošević, J. (2012-1): Eco-friendly Corrosion Inhibitors of Aluminum and Copper Alloys. Materials Protection 53. Vol. 4., 313-323. (original name of paper and journal: Ekološki prihvatljivi inhibitori korozije legura aluminija i bakra. Zaštita materijala 53. broj 4. p. 313-323.)

Stupnišek - Lisac, E. (2007): Corrosion and Protection of Construction Materials. Faculty of Chemical Engineering and Technology, Zagreb, p. 218. (original name of paper and journal: Korozija $\mathrm{i}$ zaštita konstrukcijskih materijala. Zagreb, Fakultet kemijskog inženjerstva i tehnologije. p.218.)

Velázquez-González, M. A., Gonzalez-Rodriguez, J. G.,, Valladares-Cisneros, M. G., Hermoso-Diaz, I. A. (2014): Use of Rosmarinus officinalis as Green Corrosion Inhibitor for Carbon Steel in Acid Medium. American Journal of Analytical Chemistry. 5, 55-64 


\section{Summary/Sažetak}

Zbog porasta svijesti o očuvanju životne sredine, poraslo je interesovanje za zamjenom toksičnih inhibitora korozije ekološki prihvatljivijim. Hromati, kao jedni od najboljih inhibitora, zbog izražene toksičnosti, uklonjeni su kao tehnički primjenjivi inhibitori, a smanjena je upotreba i polifosfata jer remete ravnotežu u biljnom svijetu. Akcenat je dat ka istraživanja i ispitivanju organskih spojeva koji se mogu dobiti iz biljnog materijala. Pokazalo se da ekstrakti ruzmarina (iz lista i cvijeta) imaju inhibitorsko djelovanje na koroziju željeza u 3\% rastvoru $\mathrm{NaCl}$ i morskoj vodi. Vrijednosti brzine korozije pokazuju da su ekstrakti cvijeta ruzmarina bolji inhibitori korozije od ekstrakta lista, i da nije dostignut maksimum inhibitorske zaštite u rasponu ispitivanih koncentracija. 